Artur Miazek

University of Warsaw

Artur Podleśny

University of Warsaw

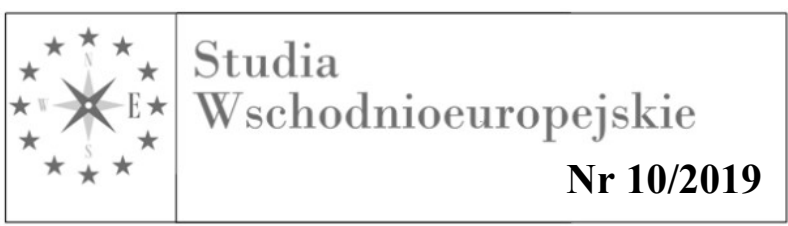

\title{
Sport mega-events as part of foreign policy of BRICS countries
}

\begin{abstract}
T $\mathrm{n}$ times of globalization an developing mass media sport has become a global social phenomenon. It significantly transgresses categories such as education, physical and mental development, as well as Olympic rivalry. Contemporary sport (especially when performed professionally) is a marketing product, delivered to people all over the world in an appropriate form. The best example of this are so called sport mega-events whose range and influence can reach even up to billions of people.
\end{abstract}

The inclusiveness of sport caused that it has been added to global politics as one of important elements. Countries began to use sport mega-events as a way to execute their goals in fields of both national and foreign policy. This resulted in the fact that international relations studies show increasingly more interest in sport and its connections with international affairs. They are widely analyzed, mainly in terms of liberal theory of internal relations 33 . What is more, certain new concepts, like sport policy (policy on sport) or international sports relations have been created in political studies. The first is understood as one of "particular politics" executed by a country which uses sport as a tool to achieve significant social gains such as social consensus or promoting national prestige 34 . The second term can be defined as one of the areas of contacts between national sport organizations, which (maintained between two or more subjects), create the basis for cooperation in the field of sport. This cooperation often shows more or less direct political motivations which can be inspired by decisions made by the countries involved 35 .

Increasing activity in the area of organizing sport mega-events among the so-called emerging powers (especially the countries included in the BRICS group) is also a process which is both related to sport and international relations. The aim of this study is to show the motivations which inspire the BRICS countries to organize sport mega-events in the context of their foreign policy. The Authors have analyzed global aspirations common to all of the countries described and also these particular characteristic for every nation organizing an event. The Authors have also tried to estimate if these countries succeeded in executing their goals. In this article, the concept of sport mega-events will be used in the understanding proposed by

\footnotetext{
33 The inclusion of sport into the research field of international relations is widely analyzed in: A. Budd, R. Levermore (eds.), 2003.

34 Bloyce D., Smith A., Sport Policy and Development: An Introduction, 2009.

35 Młodzikowski G., Polityka i sport, Warszawa, 1979, p. 145.
} 
Müller36. On the basis of the index which he created, Müller divided sports events into three types:

- giga-event (Summer Olympic Games),

- mega-event (FIFA World Cup, UEFA European Championship, Winter Olympic Games and Asian Games),

- major event (e.g. Commonwealth Games, Universiade, Rugby World Cup, Pan American Games).

\section{BRICS Countries as Hosts of Sport Mega-Events}

BRICS is an acronym for the names of five emerging economies: Brazil, Russia, India, China, and South Africa. Jim O'Neill, the former chairman of Goldman Sachs Asset Management, was the first to use the term BRIC (at that time without South Africa) in his article published in 2001. In this article he suggested creating an alternative for the G7 group37. The first meeting of the ministers of foreign affairs of the BRIC countries took place during the United Nations General Assembly in 2006. At present, BRICS (from 2011 including South Africa) is an informal group which has its assemblies annually since 2009. The aim of these meetings is to state objectives which these countries are to face 38.

BRICS's global aspirations presented during the summits encompass a number of targets, such as negating western neoliberalism as the universal solution for social development, pursuing the multipolarity and seeking a more important role of the developing countries in the world economy39. In order to realize these aspirations the BRICS countries attempt to strengthen their position in the arena of international politics, also using soft power among their means. Readiness to host sport mega-events is one of their tools.

The period between the 20th and 21st century is a time when an increased interest in organizing sport mega-events among the BRICS countries can be observed. Beijing aspired to organize the 2000 Summer Olympic Games, Cape Town (RPA) to host 2004 Summer Olympic Games and Brazil to organize the 2006 FIFA World Cup. However, these candidacies were finally unsuccessful - Beijing lost to Sydney, Cape Town received less votes than Rome and Athens and Brazil withdrew from the contest three days before the voting. Beijing's victory in obtaining the right to host 2008 Summer Olympic Games was the first breakthrough. Since that the BRICS countries have been or are going to be hosts of the most of sport mega-events, as classified by Müller. They have also hosted many (less global) major events.

S. Cornelissen lists three basic factors which motivate the BRICS countries to host sport mega-events 40 :

- showing economic achievements in the arena of international politics,

- using these events as international diplomatic tools,

- including them in the means of creating soft power.

36 Müller M., After Sochi 2014: costs and impacts of Russia 's Olympic Games, 2015, p. 636.

37 O’Neill J. (2001). Building Better Global Economic BRICs. Global Economics Paper No: 66, za: http://www.goldmansachs.com/our-thinking/archive/archive-pdfs/build-better-brics.pdf (28.02.2018).

38 Sporek T., BRICS jako nieformalny blok współpracy. In T. Sporek, K. Czech, Państwa grupy BRICS i ich znaczenie we współczesnej gospodarce światowej, Katowice 2015, p. 13-14.

39 Cimek G., Globalne aspiracje grupy BRICS. Przestrzeń Społeczna (Social Space), 2013, tom 3 nr 1.

40 Cornelissen S., The Geopolitics of Global Aspiration: Sport Mega-events and Emerging Powers, 2010, p. 3010. 
There are no controversies when it comes to the first motivation. Despite the differences in the pace of development and in the attitude towards economical policy, every BRICS country achieved (in various times) significant economic growth in the last two decades. According to Goldman Sachs' prognosis, the BRICS group will constitute almost $40 \%$ of global GDP by 2050, whereas its countries will become four out of five world's largest economies, with China being the largest, India the third, Brazil the fourth and Russia the fifth economy41. What is more, areas and population potentials of these countries lead them to pursue a role more significant than this of a local power. The BRICS countries seek to play a prominent role in the world's policy, thus attempting to shape the multilateral global order. Hosting sport mega-events can help them prove the ability to successfully handle an event with a cost reaching tens of billions of dollars. In this way they aim to situate themselves among the most developed countries which for many years have organized similar global events. The words of Brazil's ex-president Luiz Inácio Lula da Silva are particularly interesting in this context: "Today is the day that Brazil gained its international citizenship. Today is the day that we have overcome the last vestiges of prejudice against us... Brazil has left behind the level of second-class countries and entered the rank of the first-class countries..."42. Hosting sport mega-events is therefore a way to build credibility which can attract other countries, as well as international corporations and potential investors.

These events are also used by the BRICS countries as an instrument for public and cultural diplomacy. Public diplomacy should be understood as obtaining sympathy of other nations and their societies in terms of a country's image, policy and society by creating a certain image. Cultural diplomacy is an element of this diplomacy. It aims to promote and expose vital assets from the area of culture and science with the incorporation of e.g. the newest media43.

Sport mega-events, the Summer Olympic Games and the FIFA World Cup in particular, attract thousands of visitor to the country-host. It is estimated that Beijing (the 2008 Summer Olympic Games) was visited by around 320 thousands foreigners, Rio de Janeiro (the 2016 Summer Olympic Games) by around 410 thousands, South Africa with the 9 cities hosting games of the 2010 FIFA World Cup by approximately 310 thousands, while the 12 Brazilian cities during the 2014 FIFA World Cup were the destination for over 1 million foreign tourists. This data clearly shows the diplomatic potential of sport mega-events. What is more, these events can also influence the audience who follow them via mass media. For example, 3.6 billion people watched at least one minute of dedicated coverage of the 2008 Summer Olympics (according to the International Olympic Committee's official report), which constituted $83 \%$ of potential television audience. The average viewing per minute reached 160 million viewers 44 . Moreover, the FIFA report states that the 2014 World Cup reached 3.2 billion people viewing rate per minute, and the average live game viewing was

41 Keohane D. (2010). Goldman Sachs: Brics in 2050, za: https://www.ft.com/content/ 937ba4d9-563b-3a69b6b7-2b339dea124c (28.02.2018).

42 Bellos A. (2014). Brazil's politicians banking on World Cup victory to help soothe unrest, za: https://www.theguardian.com/football/2014/jun/08/brazils-politicians-banking-on-world-cup-victory-to-helpsoothe-unrest (28.02.2018).

43 Sutor J., Prawo dyplomatyczne i konsularne. Edition 12. Warszawa, p. 145.

44 Games of the XXIX Olympiad, Beijing 2008 - Global Television and Online Media Report 2008 (2009), za: https://stillmed.olympic.org/Documents/IOC_Marketing/Broadcasting/Beijing_2008_Global_Broadcast _Overview.pdf(28.02.2018), p. 2. 
on the level of 186.7 million45. Even if this data may seem to be overestimated, it is hard to find another event from an area different than sport with an equal capability of encompassing such amounts of spectators and attracting their attention. On the other hand, this kind of media coverage may bring results negative in terms of image, due to the media's tendency to focus on weaknesses and faults of a given situation. This is precisely the situation of the 2016 Olympic Games in Rio de Janeiro, which will be addressed in the section devoted to Brazil.

The BRICS countries also use sport mega-events to promote their culture and history thus creating a new, positive image. This is particularly crucial in their case due to the fact that their reception in the arena of international politics is often negative. Opening and closing ceremonies of the Olympic Games are a unique chance to present cultural, historical and social values of a given country. These ceremonies are transmitted in almost every country, reaching a very high viewing rate (some estimations claiming even several billions of viewers). The 2008 Summer Olympic Games Opening Ceremony is a good example. According to some data, the viewing rate reached even 4 billion spectators 46. Moreover, its reception was very positive, with some media describing it as the 'greatest ever' Olympic opening show 47. Opening ceremonies are also a convenient occasion for informal meetings between representatives of participating countries. The Beijing ceremony was attended by the highest-level dignitaries from over 100 countries.

J. Grix and D. Lee suggest that sport (including sport mega-events) is understood across cultures and it also represents values common to the vast majority of the world's population. Sport success, especially when hosting an event, is therefore an appropriate product for diplomacy 48. It can be used both on internal (creating national identity, sense of community, national pride, etc.) and international level politics (creating an image of a well-organized country characterized by a highly developed sport culture). For these reasons hosts of sport mega-events attach big importance to preparations so that their country can win as many medals as possible, often using forbidden methods or even national institutions49.

The BRICS countries use sport events also to strengthen their mutual relations. One day after the 2014 FIFA World Cup, the 2014 BRICS summit was started. It resulted in the inauguration of the New Development Bank, a multilateral development bank intended as an alternative to the World Bank and the International Monetary Fund. This proximity in time was not coincidental. Media's interest in the World Cup was supposed to attract more attention to the summit. The 2017 BRICS Games hosted by China was another initiative intended to develop mutual partnership in sport and to promote friendship between the BRICS countries. Next editions of this event are to take place in countries which will host the future BRICS summits.

\footnotetext{
45 Television Audience Report for the 2014 FIFA World Cup (2014), za: http://resources.fifa.com/ $\mathrm{mm} /$ document/affederation/tv/02/74/55/57/2014fwcbraziltvaudiencereport(draft5) te14.12.15)_neutral.pdf(28.02.2018).

46 Cody E., Fan M., Drew J. (2008). A Spectacular Opening to the 29th Olympiad, za: http://www.washingtonpost.com/wp-dyn/content/article/2008/08/08/AR2008080801134_pf.html (28.02.2018).

47 Ruwitch J., World Media Hails Beijing's Perfect Night., 2008.

48 Grix J., Lee D., Soft Power, Sports Mega-Events and Emerging States: The Lure of the Politics of Attraction., 2013 , pp. 529.

49 For example China and Russia won medal classifications during the events they hosted. Brazil in the Rio de Janeiro Olympics won the most medal, doubling their previous record from the 2004 Olympics. During 2010 Commonwealth Games in New Delhi Hindu athletes won 101 medals, compared to 69 (second best score) won in 2002.
} 
The last motivation of organizing sport mega-events listed by Cornelissen is using them as an element of soft power. The term was introduced by Joseph Nye, who defines it as a country's ability to influence other countries' preferences so that they act according to the country's national interest. This influence comes via the country's own attractiveness of culture, values, or foreign policy50. Basing on this definition, M. Foulon criticizes the assumption that the fact of hosting sport mega-events by the BRICS countries can be acknowledged as using soft power. He lists four arguments to support his thesis. Firstly, he points that the term was used by Nye in the context of the late 20 th century United States, so there is no reason to transfer it onto the $21_{\text {st }}$ century BRICS countries. Secondly, he notes that it is not the task of soft power to first invest billions of dollars in an event and only after that expect results. According to him, soft power is not a tool which can be bought in a shop. Thirdly, Foulon says that another element which is included in soft power are political values both from internal and foreign areas. This means the exclusion of Russia and China due to their authoritarian regimes and increasingly aggressive international policies led by them (e.g. the war in Donbass or the South China Sea conflict). Finally, he signalizes that other participants of the international relations do not share the same purposes as the BRICS countries, at least not without a clear sense of danger51. By analyzing the arguments mentioned above it can be stated that hosting sport mega-events by the BRICS countries is not soft power per se, but it is an element of creating prestige and persuasive influence on other countries. This, as a consequence, should lead to a future ability to impact other subjects via soft power in Nye's understanding of the term.

The next part of this work presents case studies of individual BRICS countries with respect to their approach towards organizing sport mega-events.

\section{Russia}

One of the most basic assumptions of Russia's sport policy is a pursuit to obtain rights to host sport mega-events, which is particularly visible during Vladimir Putin's presidency. This aim can be achieved due to the country's stronger economy, which allows to invest larger sums of money in sport infrastructure. The Russian authorities follow a consequent strategy to promote their country via sport, because they acknowledge various benefits (both in internal and foreign policy) stemming from it. There are many important goals which are sought to be achieved by hosting sport mega-events. The first is to shape Russia's international image as a internally developed modern world power. With this come the sense of pride and uniqueness of the Russian society, which sometimes transforms into the feeling of superiority in comparison with other nations. Next factor is to turn the citizens of Russia and global public eye's attention from the country's numerous internal struggles. Finally, creating a new international tourist centre is another valid point.

The figure of Vladimir Putin is also not without significance when it comes to Russia's sport policy. The president of the Russian Federation, known for his passion for sport, has been connected to various forms of exercises since his childhood. He started with boxing, then came sambo (a Russian martial art), and finally judo. He has also gained the eighth karate kyokushin dan and the ninth Korean taekwondo dan. Some of the people who surround him are also his former martial arts partners, e.g. Arkady and Boris Rotenberg, the current owners of the SMP

\footnotetext{
50 Nye J. S., Soft Power. Jak osiagnąć sukces w polityce światowej, Warszawa 2007, p. 25.

51 Foulon M. (2014). BRICS host sports events to boost prestige, just don't call it 'soft power', za: https://theconversation.com/brics-host-sports-events-to-boost-prestige-just-dont-call-it-soft-power-29177 (28.02.2018).
} 
bank, who are the main beneficiaries of the controversial deals connected with the 2014 Sochi Winter Olympic Games. Apart from that, the Russian president personally supports the cities' efforts to gain the rights to host the most important sport events. His commitment can be confirmed by the fact that he himself presented the candidacy of Sochi during the meeting of the International Olympic Committee. He delivered his speech in English and French publicly for the first time, which added even more publicity to this event 52.

The 2014 Sochi Winter Olympic Games are the most important event organized in Russia in the recent years. This event aimed at leaving behind the country's image of a poor and undeveloped nation and turning to a new phase of its development. The Games, just after their end, had to be acknowledged as Russia's great success, both in terms of organization and sport. Russia was first in the medal classification, having won 33 (of which 13 gold) medals. However, it was impossible to achieve without naturalized foreign athletes. Furthermore, Russia presented itself as a well-organized host of a significant sport event, providing efficient public transport and volunteers53.

However, the Sochi Olympic Games are a good example of how the evaluation of an event can change after a certain period of time. The annexation of the Crimea and military actions in eastern Ukraine annihilated Russia's efforts to create its new image. It also has to be noted that protests in Kiev's Independence Square (known as Euromaidan) originated during the Games.

By analyzing foreign press it can be observed that Russia did not manage to achieve the intended media success. Newspapers at that time mainly dealt with the rights of the homosexual in this country or scandals connected with activists such as The Pussy Riot group54. Moreover, the achievements of the Russian athletes were diminished by the accusations of mass usage of forbidden doping substances. The number of medals won by Russia melted by 13 in the peak moment of the investigation. However, after the CAS's decision from 1st February 2018 the country has 29 medals.

Another issue which came to light was the range of corruption and embezzlement connected with the organization of the Games. It is estimated that due to this fact the cost of the event (51 billion dollars and 16 billion for sports-related costs) was higher than every other Winter Olympic Games added up55.

The future of sport mega-events in Russia seems to be equivocal. On one hand, this country hosts the 2018 FIFA World Cup, which is connected with big publicity and opportunities to present its strength, but also with much bigger organizational challenges. On the other, however, the Russian authorities cannot hope for sport federations' favor in evaluating its cities' future candidacies. The doping scandal has had a big impact on the image of Russian sport. It also had direct consequences - the country was deprived of the rights to host the 2017 Bobsleigh and Skeleton World Championships in Sochi and the 2021 Biathlon World Championship in Tyumen. Similar actions can be expected in the future - not only can Russia be deprived of rights to host an event, but also its candidacies may be rejected. For example, despite the fact that Russia was originally announced as the host of the II European Games,

\footnotetext{
52 Kobieracki M., Dyplomacja krykietowa Indie-Pakistan jako forma dialogu między skonfliktowanymi państwami., 2016 a.

53 Eadem, Russia and Its International Image: From Sochi Olympic Games to Annexing Crimea., 2016b, pp. 175-176.

54 Boykoff J., Yasuoka M., Media Coverage of the 2014 Winter Olympics in Sochi, Russia: Putin, Politics, and Pussy Riot, Vol. XXIII.

55 Müller M., After Sochi 2014...op.cit., pp. 630.
} 
in November 2015 the event was relocated to Belarus. This situation will force the Russian authorities to revalue available sport diplomacy tools and to seek substitutes for sport megaevents.

\section{China}

The People's Republic of China has been seeking to host global and regional sport megaevents since the 1990s. The main assumption of this kind of policy is to create the country's positive image, undermined by many accusations (violating human rights, maintaining aggressive policy towards Tibet, the Tian'anmen Square Massacre in 1989, non-democratic system or supporting the Sudanese government during the Darfur conflict56). China attempts to present itself as a highly developed power with global aspirations, which successfully performed economical reforms started at the end of the 70s by Deng Xiaoping leading to the introduction of Chinese version of capitalism. Using sport mega-events the country may present its achievements in economy and science together with its cultural heritage. It is well reflected in the 2008 Beijing Olympics official report, which lists Green Olympics, High-tech Olympics and People's Olympics as main concepts of the games57.

On the regional level, hosting regional and sub-regional sport events can be recognized as an element of the Peaceful Rise Strategy - a policy officially announced by $\mathrm{Hu}$ Jintao. It is supposed to be the answer to the so called "China Threat" theory originating in international relations studies. This threat is especially feared in the eastern and south-eastern Asia, due to China's growing economical potential and conflicts with the countries located in these regions 58 .

The 2008 Beijing Summer Olympic Games are so far the most important sport event in the country's history. This event resulted in a double success - organizational and sporting. All of the works connected with the Games met their deadlines, with some of the facilities even with 12 months' advance. Due to IOC's request motivated by the willingness to avoid maintaining unused structures for a year, the hosts agreed to postpone completing of some investments. The overall cost of the Games is estimated to be from $\$ 40$ billion to $\$ 44$ billion. Until the 2014 Sochi Games, these had been the most expensive games in the history. According to the Chinese authorities, the costs should recompense in foreign investments and in tourism.

During the Games China led an intensive marketing campaign, called "the battle for the foreigners' minds" 59 . To help build the image of a superpower, the country also aimed at sport success. The 1980s was a time of a real breakthrough in Chinese sport. China has been taking part in the Asian Games since 1974, but it was not until 1982 that it won the first place in the medal count over its regular winner, Japan. Since that time, the People's Republic of China has been the winner of every edition of the Asian Games. Thanks to the first in 32 years start in the 1984 Summer Olympic Games, the country established its position as a sport potentate 60.2001

\footnotetext{
56 Supporting the Sudanese government was the official reason for Steven Spielberg's resignation from the role of an advisor for the 2008 Summer Olympics opening ceremony.

57 Bid Documents and Analysis: Passion behind the Bid. Official Report of the Beijing 2008 Olympic Games, pp. 21.

58 Zhou Y., Ap J., Bauer T. Government motivations for hosting the Beijing 2008 Olympic Games, 2012, pp. 193. 59 Ibidem., pp. 148.

60 Despite the fact that China's Summer Olympic Games participation record reaches 1924, its athletes had not won any medal until 1960. Till 1972 China had been represented only by athletes from the Republic of China, currently known as Chinese Taipei. The People's Republic of China had its symbolic debut during the 1952
} 
is another significant date for Chinese sport - it was the year when the IOC decided to give the rights to host Olympic Games to Beijing. In order to prepare to the event, many foreign sports coaches were employed and many teams of sports previously unpopular (e.g. yachting or synchronized swimming) were built anew. In this way China won the first place in the medal count with the number of 100 medals (48 gold), which after the dissolution of the USSR seemed to belong to the USA. This success could be achieved due to a long-term strategy of recruiting new talents and working with the young. The results of China's athletes presented in the chart 1 are the best illustration of the country's dedication to Olympic sports development. Moreover, the image of China as a modern country was supposed to be created with the new modern arenas - e.g. the Olympic Stadium (known as the Bird's Nest) or the international design awardwinning Olympic swimming pool (the Water Cube).

China is most likely to continue its policy oriented on hosting the largest number of sport events. This strategy can be realized due to a good economic situation, the country's rise in significance in the international arena and the authorities' persistent pursuit to create China's image via sport. The year 2022 will be particularly important, when two big events - the Asian Games in Hangzhou and the Winter Olympics in Beijing will be hosted. The sole fact of acquiring the rights to host the latter event is China's great success. Beijing will be the first city in the history where both Summer and Winter Olympics took place. However, organizing this event will be the country's serious organizational and logistic challenge. Only some parts of the infrastructure built for the Summer Olympics can be accommodated to the requirements of winter sports specifics. Many venues will have to be constructed from the scratch. Beijing's localization, distant from the mountain area, where many competitions will take place, is another problem. What is more, it will be difficult to replicate the 2008 sport success, because winter sports are much less rooted in China's culture. As the results of the 2018 PyeongChang Winter Olympics show, China is not a winter sport potentate.

\section{Chart 1. Medal achievements of China at the Summer Olympics}

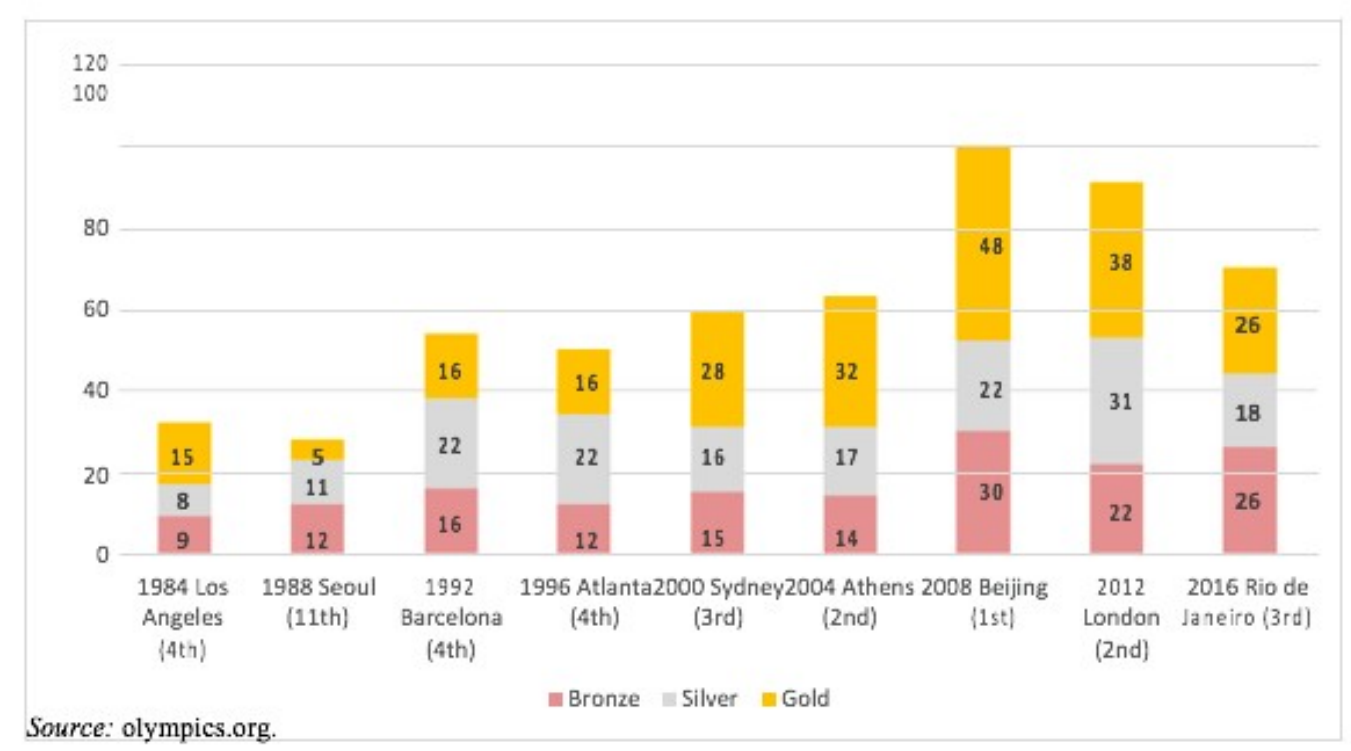

Helsinki Olympics (with only one athlete). However, until 1984 it had been boycotting all the other editions of the Games due to the participation of the Republic of China which it did not want to acknowledge. 


\section{Brazil}

In the case of Brazil the question of hosting sport mega-events is necessarily connected with the vision of Luiz Inácio Lula da Silva, the country's ex-president. During his presidency he attempted to create Brazil's independent position in the international arena, shaping its image of a regional leader and an important international actor. Pursuing Brazil's inclusion to the United Nations Security Council as a permanent member, lessening the role of pro-USA strategies, turning to emerging states via creating the IBSA (India, Brazil, South Africa) Dialogue Forum and participating in the BRICS group - these are the most obvious elements of this policy. Another element in Lula's vision was hosting two sport mega-events in a short period of time - the 2014 FIFA World Cup and the 2016 Summer Olympics61. This direction of Brazil's international policy was then continued by Dilma Rousseff, who emphasized that the country has to seek not only economical growth but also cultural presence in the world62.

The time of Lula's presidency saw circumstances friendly towards hosting such events and realizing goals which were connected with them. Brazil was experiencing constant economical growth and social reforms were effective. At the end of his second term of office Lula noted 80\% support in opinion polls (Datafolha, 2011). However, this situation changed during the rule of Dilma Rousseff, when the country's economical development slowed down and its GDP shrank by $0.1 \%$.

Economic problems together with corruption scandals and growing costs of organizing the World Cup and the Olympic Games radically lessened the social support for hosting these events. In 2013 the first wave of protests appeared, with demonstrations taking place during the FIFA Confederations Cup. Images such as throwing stones at the bus transporting the FIFA officials or using force by the police when dealing with the protesters were widely present in the world media63.

The next wave of protests came before the start of the 2014 FIFA World Cup. Protests were organized in all of the cities were the tournament was held, but their scale was significantly smaller than those from 2013. Research shows that in the time of the World Cup preparations Brazil's media reception was rather negative. This situation changed during the World Cup, when the country and the event started to be perceived in more positive terms. Media emphasized organizational success and big numbers (over 1 million) of foreign tourists.

When it comes to the 2016 Summer Olympic Games, the situation was remarkably worse, mainly due to the country's difficult political circumstances at that time. In May 2016 Rousseff was suspended by the senate on the grounds of corruption accusations. Lula was also included in the criminal proceedings. This political crisis led to more protests. Opinion polls showed that an increasing number of Brazilian citizens opposed the organization of the Olympics64. Because of this media started to enunciate the first in a long time "Olympics without politicians".

\footnotetext{
61 de Alemida B. S., Marchi Júnior W., Pike E., The 2016 Olympic and Paralympic Games and Brazil's soft power., 2014, pp. 276.

62 Foulon M. BRICS host sports events to...op.cit., 2014.

63 PAP (2013). Puchar Konfederacji przerwany? Działacze FIFA obrzuceni kamieniami, za: https://www.polskieradio.pl/43/265/Artykul/871187,Puchar-Konfederacji-przerwany-Dzialacze-FIFAobrzuceni-kamieniami (28.02.2018).

64 In the poll conducted by Datafolha from July 14-15 2016 over 50\% of responders claimed to be in opposition to the Olympics (The Associated Press, 2016). The poll conducted in the time of Rio de Janeiro's official candidacy to host the event showed the support of $81 \%$ of the city's population for this initiative.
} 
There were also other factors which led to a negative perception of the Games: delayed realizations of the infrastructure (including the Olympic Village), the Zika virus threat popularized in media (the cause of some athletes resignation from the participation), bad condition of the aquatics stadium or numerous thefts reported by athletes and journalists. The Games did not contribute to improve Brazil's image, its position in the region and in the international arena. They only strengthened the country's stereotypes, e.g. poverty in favelas, social inequality, corruption, crime, or unstable political situation.

\section{South Africa}

After finishing the era of apartheid, the Republic of South Africa started efforts to create its new image. Apart from classic diplomatic means, the country also turned to sport mega-events. When one takes into consideration the fact that South Africa from the 1960s till the end of apartheid was excluded from the IOC and other international sport federations, this renewed integration with the sport movement has to have its symbolic value.

At the beginning of the 1990s the country began its pursue to win rights to host international sport events. In 1995, three years after its readmission to the International Rugby Football Board (IRFB), it hosted the Rugby World Cup. The year 1996 was the date of the African Cup of Nations and 1999 - of the All-Africa Games. However, these events were not of global significance and could be diplomatically used only in a limited spectrum.

Obtaining the rights to host the 2010 FIFA World Cup in 2004 was a major breakthrough. It was the first global sport event in the African continent. The country's authorities wished to use this event to achieve global goals as well as to strengthen the South Africa's position in Africa.

Among the global goals, improving the country's image was particularly important. The shadow of apartheid was still present and new problems appeared, just to mention social inequality, high unemployment rate, increasing crime or one of the highest HIV infection rates65. The organization of the World Cup was also intended to overcome afro-pessimistic tendencies in the world, i.e. perceiving African nations only in terms of poverty, war, diseases, political and economical instability, etc. Afro-pessimism has a negative impact on the whole continent, which leads to difficulties in attracting foreign investors and tourists 66 . Social research67 points to the fact that hosting the World Cup changed the reception of South Africa. It also caused the growth of the number of foreign tourists visiting the country in the subsequent years.

Another goal connected with the fact of organizing this event was to strengthen the country's position in Africa. South Africa has often been accused by other countries from thecontinent of taking care of its own economic matters only and perceiving itself as a unique nation. This tendency is seen as the country's exclusivism. Due to this perception the candidacy of South Africa to host the 2006 and 2010 World Cup was not supported by many African states68. To change this negative attitude it was decided that the preparations and the event were supposed to proceed in the atmosphere of Pan-Africanism. The RSA's president of that time, Thabo Mbeki, announced that the World Cup is supposed to be African, not only South African.

65 Harris L., Mega-events and the developing world: A look at the legacy of the 2010 Soccer World Cup, 2011, pp. 408.

66 Cornelissen S., The Geopolitics...op.cit, pp. 3018.

67 Knott B., Fyall A., Jones I., The Nation-Branding Legacy of the 2010 FIFA World Cup for South Africa., 2013.

68 Cornelissen S., The Geopolitics...op.cit., pp. 3019. 
He emphasized that the idea of Pan-Africanism encompasses also the diasporas inhabiting the Caribbean, the United States and Brazil69.

In fact, countries forming the Southern African Development Community (SADC) were the RSA's main cooperators. Representatives of Mozambique, Swaziland and Lesotho were included in official committees which supervised the World Cup preparations. Angola, Botswana and Namibia (as potential beneficiaries) were added to the process of informing about the progress of the works. In 2009 Mozambique signed a 75 million dollar contract for the renewal of the International Airport located in this country which was to finish before the start of the World Cup. What is more, members of the Southern African Power Pool offered to share their sources of electricity for the time of the event 70 .

Considering all of the arguments mentioned above it has to be stated that the 2010 World Cup met the South African authorities' expectations.

\section{India}

Among the BRICS members India has so far been the country with the weakest initiative when it comes to hosting sport mega-events. However, it has organized some fixtures of high importance which then were incorporated into the country's international policy. The 2010 Commonwealth Games in New Delhi and the 2011 Cricket World Cup (together with Bangladesh and Sri Lanka) are two examples of such events.

The Commonwealth Games, when compared to the FIFA World Cup or the Olympic Games, do not have global range. Their media presence is limited only to the countries associated in the Commonwealth, but from the organizational point of view they are a mega scale investment. India spent 2 billion dollars on the infrastructure alone and up to 11 billion in total when the rest of the costs are added (e.g. transport facilities). With such expenditures and expected organizational success the country's government hoped to create an image of New India.

In the official bid document India was presented as one of the world's oldest civilizations, with a high level of economical and social development based on science, new technologies and IT. The choice of the city-host was not coincidental either. New Delhi, unlike other Indian big cities, could be presented as a modern, cosmopolitan metropolis, where problems of poverty, social injustice and crime are not obviously striking.

Creating the new image also meant dealing with environmental matters. The hosts presented the event as the first "Green Games" in the history which intended respect the principles of sustainable development. In order to make this claim credible in October 2007 India signed a memorandum of understanding with the United Nations Environment Programme (UNEP). In this document the country promised to implement the best international principles to make the Games "green". After that, in 2010, the Ecological Codes were announced. This document, whose implementation was intended to begin in the last few months

69 Underlining that the idea of Pan-Africanism encompasses also the diasporas, which took place during the campaign promoting the candidacy of South Africa, was aimed mainly at claiming the support of the members of The Confederation of North, Central American and Caribbean Association Football - CONCACAF,

Ndlovu S. M., Sports as cultural diplomacy: the 2010 FIFA World Cup in South Africa's foreign policy., 2010, pp. 147-148.

70 Ibidem, pp. 149. 
before the games, contained statements like enhancing energy efficiency or improving the air quality by increasing the city's forestation 71 .

However, the hosts did not manage to achieve their previously assumed objectives. Organizational problems were already visible before the start of the event. The estimated budget was significantly exceeded and reports published several months before the inauguration pointed to the fact that the works on many venues (including the most important, Jawaharlal Nehru Stadium) were not conducted in accordance with the schedule72. Moreover, due to the 2008 Mumbai terrorist attacks, some of the events preceding the Games were relocated from India's territory and a number of athletes decided not to participate in them (e.g. in the 2009 Badminton World Championships). During the event media presented India as a country not prepared to host of the Games. They noted drawbacks such as bad conditions in the Commonwealth Games Village, dirt, piles of debris, wandering dogs or increased risk of dengue fever infection 73 .

On the contrary, the 2011 Cricket World Cup was completely different when it comes to India's international policy. Cricket is the most popular sport in South Asia and for this reason games on the international level (both test and during championships) focus a lot of attention. Matches between India and Pakistan were often used as a tool to improve these two countries' relations. Political studies call this form of diplomacy "cricket diplomacy". This method was used during the 2011 Cricket World Cup, when for the semi-final game which took place in Mohali (India) the prime minister of India Manmohan Singh invited his Pakistani vis-a-vis, Yousaf Raza Gilani. The invitation was accepted and later it led to the meeting of the countries' international affairs ministers which was an attempt to improve India and Pakistan's relations.

\section{Conclusion}

The beginning of the XXI century saw a change in the geography of sport mega-events. The countries traditionally hosting these events (Western Europe and the USA) have been showing increasingly less interest in them. This role has been taken by the emerging states, where previously only lesser continental or regional contests were hosted.

The emerging states (particularly the BRICS countries) have been winning rights to organize the most important and expensive events (like the Olympic Games or the FIFA World Cup) since the start of the XXI century, and using them as elements of their internal and external policies. Having analyzed the reasons and aims of these countries for hosting sport mega-events it is easy to find the ones common for every BRICS nation and also these particular for each of them. Common reasons include a desire to show the country's power (regional and global) and economical achievements or diplomatic actions aimed at building prestige and improving image. Among particular reasons one can mention e.g. building a modern tourist center (Russia, Sochi), including the Olympic Games into Peaceful Rise

71 The 2010 Commonwealth Games Go Green (17 February 2010), za: http://staging.unep.org/ Documents.Multilingual/Default.asp?DocumentID=612\&ArticleID=6463\&l=en, (28.02.2018).

72 A series of constructional failures were noted shortly before the 2010 Commonwealth Games opening ceremony. A pedestrian bridge collapsed in the Jawaharlal Nehru Stadium as did the weightlifting arena's ceiling. See: Commonwealth Games 2010: crisis... (22 September 2010), za: https://www.telegraph.co.uk/sport/othersports/ commonwealthgames/8017838/Commonwealth-Games-2010crisis-worsens-as-portion-of-weightlifting-arena-roof-caves-in.html

Rahman S. S., The 2010 Commonwealth Games: India's Triumph or Disaster?, 2010.

73 Jakubowski J., Wielkie imprezy sportowe w stużbie budowania wizerunku państw. Przykład grupy BRIC. Refleksje, 2012, pp. 42. 
Strategy (China), supporting the Pan-African movement (South Africa) or using the Commonwealth games as an element of the so-called green policy (India).

The attempt to realize the goals listed above show how non-uniform the BRICS group in fact is. The nations differ in terms of organizational abilities, economy, political systems and social structure. These factors were crucial for the success or failure in the preparations and organization of a sport mega-event in these countries. For example, Brazil and India found it more difficult to use their events to build an image of a power due to the necessity to consider the public eye. It led to limiting the costs of the events which resulted in numerous delays and shortcomings. As a consequence, the reception of these events in media was largely negative. On the other hand, authoritarian countries like Russia and China could afford to spend billions of dollars without any harm to their internal affairs and did not have to consider environmental matters. They also could spend larger sums on external propaganda.

It is difficult to predict if the emerging states will be willing to host such a big number of sport mega-events in the future. International sport federations are trying to divert this tendency and turn back to the customary hosts. It is visible in giving the rights to organize the 2024 and 2028 Summer Olympics to Paris and Los Angeles. Thomas Bach, the IOC president, said that also the Winter Olympics should find their origins. However, it is possible that the Eastern countries will continue not to show their interest in hosting sport mega-events. This situation may create opportunities for other emerging states.

\section{Streszczenie:}

Celem artykuły jest analiza zalezności między organizacją dużych wydarzeń sportowych a częścią polityki w ramach BRICS. Rosja, Chiny, Indie, Afryka Południowa i Brazylia to regiony mające największe możliwości organizatorskie względem tak dużych wydarzeń jak Mistrzostwa Świata czy FIFA World Cup. Tym samym mają możliwości wpływania na politykę globalną i wykorzystywania jej w swoich celach. W XXI wieku sport jest jednym z czynników wykorzystywanych podczas prowadzenia polityki krajowej, któßy znacznie wpływa na wymienione państwa.

\section{Słowa klucz:}

BRICS, Piłka Nożna, Mistrzostwa Świata

Keywords:

BRICS, Football, World Cup

\section{Bibliografia:}

1. AFP, Press Hails 'Greatest Ever' Olympic Opening Show, 2008, za: https://web.archive.org/web/20120805025950/http://afp.google.com:80/article/ALeq M5ib NAUAq-kZNOy3LmO9HAI2cN-smg (28.02.2018). 
2. Alekseyeva A., Sochi 2014 and the rhetoric of a new Russia: image construction through mega-events, 2014, pp. 158-174.

3. Bellos A. (2014). Brazil's politicians banking on World Cup victory to help soothe unrest, za: https://www.theguardian.com/football/2014/jun/08/brazils-politiciansbanking-on-world-cup-victory-to-help-soothe-unrest (28.02.2018).

4. Bid Documents and Analysis: Passion behind the Bid. Official Report of the Beijing 2008 Olympic Games. Volume I.

5. Bloyce D., Smith A., Sport Policy and Development: An Introduction, 2009.

6. Boykoff J., Yasuoka M., Media Coverage of the 2014 Winter Olympics in Sochi, Russia: Putin, Politics, and Pussy Riot, Olympika: The International Journal of Olympic Studies, Vol. XXIII, pp. 34-42.

7. Budd A., Levermore R., Sport and International Relations: An Emerging Relationship, 2003.

8. Cimek G. (2013). Globalne aspiracje grupy BRICS. Przestrzeń Społeczna (Social Space), 3/1 (5), pp. 128-158.

9. Cody E., Fan M., Drew J. (2008). A Spectacular Opening to the 29th Olympiad, za: http://www.washingtonpost.com/wpdyn/content/article/2008/08/08/AR2008080801134_pf.html (28.02.2018).

10. Cornelissen S., The Geopolitics of Global Aspiration: Sport Mega-events and Emerging Powers, 2010, pp. 3008-3025.

11. Croft S., South Asia's Arms Control Process: Cricket Diplomacy and the Composite Dialogue. 2005, pp. 1039-1060.

12. Datafolha (2011). Opinião Pública - 20/12/2010 - Acima das expectativas, Lula encerra mandato com melhor avaliação da história, za: https://web.archive.org/web/20111017020016/

$z a:$ http://datafolha.folha.uol.com.br/po/ver_po.php?session=1122 (28.02.2018).

13. de Alemida B. S., Marchi Júnior W., Pike E., The 2016 Olympic and Paralympic Games and Brazil's soft power, 2014, pp. 271-283.

14. Foulon M. (2014). BRICS host sports events to boost prestige, just don't call it 'soft power', za: https://theconversation.com/brics-host-sports-events-to-boost-prestige-justdont-call-it-soft-power-29177 (28.02.2018).

15. Games of the XXIX Olympiad, Beijing 2008 - Global Television and Online Media Report $2008 \quad$ (2009), za: https://stillmed.olympic.org/Documents/IOC_Marketing/Broadcasting/Beijin g_2008_Global_Broadcast_Overview.pdf (28.02.2018).

16. Grix J., Lee D., Soft Power, Sports Mega-Events and Emerging States: The Lure of the Politics of Attraction., 2013, pp. 521-536.

17. Harris L., Mega-events and the developing world: A look at the legacy of the 2010 Soccer World Cup., 2011, pp. 407-427.

18. Hiller H. H., Wanner R. A., Public Opinion in Olympic Cities: From Bidding to Retrospection., 2017, pp. 1-32.

19. Holtzhausen D., Fullerton J., The 2010 FIFA World Cup and South Africa: A study of longer-term effects and moderators of country reputation., 2015, pp. 185-198. 
20. Jakubowski J., Wielkie imprezy sportowe w służbie budowania wizerunku państw. Przykład grupy BRIC. Refleksje, wiosna 2012, pp. 27-44.

21. Keohane D. (2010). Goldman Sachs: Brics in 2050, za: https://www.ft.com/content/ 937ba4d9-563b-3a69-b6b7-2b339dea124c (28.02.2018).

22. Knott B., Fyall A., Jones I., The Nation-Branding Legacy of the 2010 FIFA World Cup for South Africa., 2013, pp. 569-595.

23. Kobieracki M., Dyplomacja krykietowa Indie-Pakistan jako forma dialogu między skonfliktowanymi państwami., 2016a, pp. 15-26.

24. Kobieracki M., Russia and Its International Image: From Sochi Olympic Games to Annexing Crimea., 2016b, pp. 165-186.

25. Młodzikowski G., Polityka i sport. Warszawa 1979.

26. Müller M., After Sochi 2014: costs and impacts of Russia ’s Olympic Games. 2015, pp. 628-655.

27. Müller M., What makes an event a mega-event? Definitions and sizes. Leisure Studies, 34 (6), 2015, pp. 627-642.

28. Ndlovu S. M., Sports as cultural diplomacy: the 2010 FIFA World Cup in South

29. Nye J. S., Soft Power. Jak osiagnać sukces w polityce światowej. Warszawa 2007.

30. O’Neill J., Building Better Global Economic BRICs. Global Economics Paper No:2

31. PAP (2013). Puchar Konfederacji przerwany? Działacze FIFA obrzuceni kamieniami, za: $\quad$ https://www.polskieradio.pl/43/265/Artykul/871187,Puchar-Konfederacjiprzerwany-Dzialacze-FIFA-obrzuceni-kamieniami (28.02.2018).

32. Pyffel R., Chiny w Roku Olimpiady. Państwo środka od środka. Warszawa 2008.

33. Rahman S. S., The 2010 Commonwealth Games: India's Triumph or Disaster?, 2010, pp.166.

34. Ruwitch J., World Media Hails Beijing's Perfect Night., 8 August 2008.

35. Sporek T., BRICS jako nieformalny blok wspótpracy.

36. Sutor J., Prawo dyplomatyczne i konsularne. Edition 12. Warszawa.

37. Television Audience Report for the 2014 FIFA World Cup (2014), za: http://resources.fifa.com/

$\mathrm{mm} /$ document/affederation/tv/02/74/55/57/2014fwcbraziltvaudiencereport(draft5) (issueda te14.12.15)_neutral.pdf (28.02.2018).

38. The 2010 Commonwealth Games Go Green (17 February 2010), za: $\mathrm{http} / / /$ staging.unep.org/

Documents.Multilingual/Default.asp?DocumentID=612\&ArticleID=6463\&l=en, (28.02.2018).

39. The Associated Press (2016). Poll Finds Strong Opposition Among Brazilians to Rio Games, za: https://www.nytimes.com/2016/07/20/sports/olympics/poll-finds-strongoppositio n-among-brazilians-to-rio-games.html (28.02.2018).

40. Zhou Y., Ap J., Bauer T. Government motivations for hosting the Beijing 2008 Olympic Games., 2012, pp. 185-201. 